\title{
COMPOSITION OF MARAMA BEAN PROTEIN
}

\author{
Eric O. Amonsou, John R. N. Taylor, Mervyn Beukes ${ }^{2}$ and Amanda Minnaar ${ }^{1}$ \\ ${ }^{1}$ Department of Food Science, University of Pretoria, Pretoria 0002, South Africa \\ ${ }^{2}$ Department of Biochemistry, University of Pretoria, Pretoria 0002, South Africa
}

\begin{abstract}
The protein composition of marama beans, an indigenous African oilseed legume, was determined in comparison with soya beans. Marama bean protein contained a substantial amount of tyrosine compared with soya bean protein. It was slightly richer in proline than soya. By SDS-PAGE, marama protein contained fewer protein bands compared with soya. The patterns of these bands in marama under non-reducing and reducing conditions were similar, suggesting an absence of disulphide bonds. The vicilin (7S) and acidic $11 \mathrm{~S}$ subunits seemed to be absent in marama. This is most unusual in legume proteins. Only a major basic legumin (11S) (20 kDa), medium (63 $\mathrm{kDa})$ and high $(148 \mathrm{kDa})$ molecular weight protein bands were separated for marama. Most polypeptides in the marama proteome map are basic compared with soya. Only one polypeptide match was tentatively identified compared with soya. Marama protein composition is very different from that of soya.
\end{abstract}

Key words: marama bean, soya bean, $11 \mathrm{~S}$ and $7 \mathrm{~S}$ proteins, tyrosine

\footnotetext{
${ }^{1}$ Corresponding author: amanda.minnaar@up.ac.za
} 


\section{Introduction}

Marama bean is an indigenous southern African leguminous oilseed (Coetzer \& Ross, 1976). Its protein (29-38\%) and oil (32-42\%) contents (Holse, Husted \& Hansen, 2010) are very similar to those of soya (Mujoo, Trinh \& Ng, 2003) and peanuts (Venkatachalam \& Sathe, 2006).

Very limited information is available on the protein composition of marama bean (Maruatona, Duodu \& Minnaar, 2010; Holse et al., 2010; Amonsou, Taylor \& Minnaar, 2011). Marama flour contains much higher tyrosine content $(6.2 \mathrm{~g} / 100 \mathrm{~g}$ flour) than soya bean flour (1.8 g/100 g flour) (Maruatona et al., 2010). A study of seed microstructure showed that marama bean protein bodies were similar to those of soya bean in terms of shape and localisation within the parenchyma cells (Amonsou et al., 2010). However, marama protein bodies seemed to contain spherical globoid and druse crystal inclusions, which are absent in soya (Amonsou et al., 2011).

This study compares the chemical characteristics of marama protein in terms of constituent polypeptides and their structure with those in soya. This information is required to facilitate the effective use of marama protein as a functional ingredient in food systems. 


\section{Materials and methods}

\subsection{Raw materials}

Marama bean specie Tylosema esculentum (Burch) A. Schreib was used. This was gathered from Rooidraaitrust, Gauteng Province, South Africa in 2008 (voucher specimen deposited at H.G.W.J. SCHWEICKERDT (PRU), Accession number: 113873). Soya bean (Glycine max L. Merr.) was obtained from AGRICOL, Pretoria, South Africa.

\subsection{Chemicals}

The following chemicals were used: Immobilized pH gradient (IPG) strips pH 3-11 $\mathrm{NL}$ and $\mathrm{pH}$ 6-11 and carrier ampholytes corresponding to each $\mathrm{pH}$ range; acrylamide, bisacrylamide; sodium dodecyl sulfate (SDS); N,N,N,N-tetramethyl-Ethylenediamine (TEMED); ammonium persulfate (APS); thiourea; urea; dithiothreitol (DTT); iodoacetaminde and 3-[(3-cholamidopropyl) dimethylammonio]-1-propanesulfonate (CHAPS) from GE Healthcare (Uppsala, Sweden); methanol, n-hexane, 2mercaptoethanol (2-ME), trichloroacetic acid (TCA), acetone and glycerol from Sigma-Aldrich (St. Louis, MO).

\subsection{Protein preparations}

Marama beans were dehulled using a cracker (WMC Sheet Metal Works, Tzaneen, South Africa). Soya beans were dehulled with a Tangential Abrasive Dehulling Device (TADD) (Sheperd, 1979). Dehulled marama and soya beans were coarse 
milled in a food blender. The bowl (sample holder) and blade of the blender were prechilled at $-20^{\circ} \mathrm{C}$ for 10 min to prevent heating during milling.

\subsubsection{Defatted flours}

Coarse milled flours were then defatted four times with $n$-hexane, flour: hexane ratio 1:5, for $90 \mathrm{~min}$ at room temperature. Defatted flours were placed in a fume hood overnight to remove the remaining hexane. The flours were milled in a laboratory attrition mill (Ika Werke, Staufen, Germany) and sieved through $0.5 \mathrm{~mm}$ opening screen. The protein contents of the defatted marama and soya flours were 55.7 and $50.0 \%(\mathrm{~N} x 5.71)$, respectively.

\subsubsection{Purified protein extracts}

Proteins were extracted from defatted marama and soya flours with $30 \mathrm{mM}$ Tris- $\mathrm{HCl}$ buffer (pH 8.0) containing $0.5 \mathrm{M} \mathrm{NaCl}$, at a flour to solvent ratio of 1:20 (Aluko \& Yada, 1995). Protein extraction was done at $40^{\circ} \mathrm{C}$ for $1 \mathrm{~h}$ in a shaking water bath. Crude protein contents $(\mathrm{N}$ x 5.71) of bean flours and protein extracts were determined by combustion analysis (968.06) (AOAC, 2000).

\subsubsection{Total protein preparation}

Total protein extraction was performed by the TCA/acetone precipitation method of Natarajan, Xu, Caperna and Garrett (2005), except that DTT was included. The protein precipitate was suspended in $7 \mathrm{M}$ urea, $2 \mathrm{M}$ thiourea, $2 \%(\mathrm{w} / \mathrm{v})$ CHAPS, $0.5 \%$ (v/v) IPG buffer without DTT. Protein solutions were kept at $-20^{\circ} \mathrm{C}$ until analysed. Protein concentrations were determined by the Bradford method (Bradford, 1976).

\subsection{Amino acid analysis}

The amino acid contents of bean flour and protein extracts were determined using the PICO.TAG-Method (Bidlingmeyer, Cohen \& Tarvin, 1984). This method is based on 
the principle of reverse phase chromatography with pre-column derivatization, following acid digestion.

\subsection{SDS-PAGE}

SDS-polyacrylamide gel electrophoresis (SDS-PAGE) was performed as described by (Taylor, Bean, Ioerger \& Taylor, 2007). Ten microliter of aliquots containing 10, 15 and $20 \mu \mathrm{g}$ protein was loaded onto a gradient gel of $4-12 \%$ polyacrylamide. Gels were stained with Coomassie Brilliant Blue R-250.

\subsection{Two-dimensional gel electrophoresis}

The Isoelectric Focusing (IEF) was performed using $13 \mathrm{~cm}$ IPG strips (pH 3-11 Non Linear, NL) and $\mathrm{pH}$ 6-11). The strips were focused on a gradient at $150 \mathrm{~V}$ for $2 \mathrm{~h}$, $500 \mathrm{~V}$ for $1 \mathrm{~h}, 1000 \mathrm{~V}$ for $1 \mathrm{~h}$, and $8000 \mathrm{~V}$ for $3 \mathrm{~h}$ using the Ettan IPGphor II system (Amersham Biosciences, Uppsala, Sweden). After IEF, the strips were first equilibrated in equilibration buffer with DTT and then in buffer with iodoacetamide each for $15 \mathrm{~min}$.

SDS-PAGE was carried out in a Hoefer SE 600 Ruby electrophoresis unit (Amersham Biosciences) at $30 \mathrm{~mA} / \mathrm{gels}$, voltage set at maximum. The 2-DE gels were stained with Coomassie Blue.

Gel images were acquired using a Versa Doc Documentation system (Bio-Rad, Hercules, Canada) and analyzed with PDQuest 2 D Image Software. Master gels were generated for each sample. The 2-D electrophoresis soya protein spots were identified by reference to Natarajan et al. (2005) and Zarkadas, Gagnon, Poysa, Khanizadeh, Cober, Chang, and Gleddi (2007) as well as maps from a database 
(http://oilseedproteomics.missouri.edu). It was attempted to identify the marama protein spots based on these.

\subsection{Statistical analysis}

The experiment was repeated twice. Chemical analyses were thus done on two separate protein extracts. One way analysis of variance was performed for protein content and amino acid composition and the means compared using Fisher's Least Significant Different Test at $\mathrm{p} \leq 0.05$.

\section{Results and discussion}

\subsection{Protein contents and yields of marama protein extract}

The protein content of the marama protein extract was high $(86 \%)$ and similar to that of soya (Table 1). The protein yield in the marama extract $(63 \%)$ was similar to that of soya $(65 \%)$. The method used for preparing the extracts was a standard procedure for soya (Aluko \& Yada, 1995). Therefore for the purpose of this study, the protein yields of the respective extracts were considered to be sufficiently representative.

\subsection{Amino acid profile}

The glutamic and aspartic acid, which may include glutamine and asparagine, respectively, were the major amino acids in the purified marama protein extract (Table 2) as well as in the flour (Maruatona et al., 2010). These are also the major amino acids in soya (Table 2). The lysine content of marama protein extract (5.7 $\mathrm{g} / 100 \mathrm{~g}$ protein) was also similar to that of soya. Based on the FAO/WHO (1989) recommended pattern, marama flour and protein extract are adequate sources of lysine for pre-school children. 
The tyrosine contents of marama flour and purified protein extract were very high (11 and $9 \mathrm{~g} / 100 \mathrm{~g}$ protein, respectively), almost 3 times those of soya, thus confirming other reports on marama protein composition (Maruatona et al., 2010; RippergerSuhler, 1983). In fact, the tyrosine content of marama protein was substantially higher than that in other legumes, including peanuts (Venkatachalam \& Sathe, 2006) and lupine (Lqari, Vioque, Pedroche \& Millan, 2002). Since tyrosine is involved in polypeptide crosslinking (Takasaki, Kato, Murata, Homma \& Kawakishi, 2005), the high tyrosine in marama may contribute to the structural stability of its protein as suggested for gluten (Tilley, Benjamin, Bagorogoza, Okot-Kotber, Prakash \& Kwen, 2001). The proline content of marama was also slightly higher than that of soya, which may affect its protein structure (Levit, 1981). Proline can impart a rigid structure to protein by participating in protein folding and unfolding (Levit, 1981).

\subsection{Protein subunit composition}

SDS-PAGE revealed differences in protein compositions between marama and soya (Fig. $1 \& 2$ ). The protein profiles from defatted marama and soya flours (Fig. 1) were similar to those of their respective protein extracts (Fig. 2). This indicates that these protein extracts were representative of the storage proteins of each of the respective seeds. By SDS-PAGE, marama protein contained fewer major protein bands (three) compared with soya (approx. 8) (Mujoo et al., 2003).

The patterns of these bands in marama under non-reducing and reducing conditions were similar, suggesting an absence of disulphide bonds. This was unlike the situation in soya where 11S storage proteins were separated under reducing conditions (lane 2), due to the fact that the $11 \mathrm{~S}$ acidic and basic units are linked by disulphide bonds 
(Mujoo et al., 2003; Kinsella, 1979). Further in comparison with soya bean, the acidic $11 \mathrm{~S}$ legumin subunits were absent in marama. Only a major broad band (around 20 $\mathrm{kDa}$ ), was present in marama, corresponding to a basic 11S legumin was present.

Two major higher molecular weight protein bands were also observed in marama. There was a medium intensity protein band of approx. $63 \mathrm{kDa}$. Under non-reducing conditions, this appeared to match a major band in soya. However, while this band remained in marama under reducing conditions, it disappeared in soya probably forming the $11 \mathrm{~S}$ sub-units when separated under reducing conditions. The other protein band was a very high molecular weight band (148 kDa), which did not match any bands in soya. This protein band was also not reduced by mercapthoethanol, suggesting that its constituent polypeptides are not linked together by disulphide bonds. Since marama protein contains such a high level of tyrosine compared with soya (Maruatona et al., 2010) and tyrosine can participate in polypeptide crosslinking (Tilley et al., 2001; Takasaki et al., 2005), it is suggested that dityrosine type of crosslinks may be responsible for the stability of this high molecular weight protein in marama.

Marama protein was further analysed using proteomic type 2-D electrophoresis to attempt to identify its constituent polypeptides by comparison with soya.

\subsection{Two-dimensional gel electrophoresis}

Marama appeared to contain a similar number of polypeptides to soya, as indicated by protein spots (Fig. 3, Table 3). However, the total protein of marama and its purified 
protein extract contained more basic polypeptides than those of soya (Fig. $4 \&$ Table $3)$.

As indicated by the proteome map, the vicilin $(7 \mathrm{~S})$ subunits were apparently absent in marama, unlike soya (Fig. 3). The absence of $7 \mathrm{~S}$ subunits in legumes is most unusual, if not unique. Variations in the major storage protein in terms of vicilin (7S) and legumin (11S) contents (Kinsella, 1979; Horax et al., 2004) have been reported in the literature for some legume species (Kinsella, 1979; Horax, Hettiarachchy \& Chen, 2004; Chel-Guerrero, Scilingo, Tintoré, Dávila \& Añón, 2007). For instance both 7S and 11S have been found to be major storage protein fractions of lupine (Lupinus albus) (Duranti et al., 1981) and soya bean (Kinsella, 1979) whereas the 7S has been found to be the major protein fraction of dry bean legumes such as mucuna bean (Adebowale, Adeyemi, Oshodi \& Niranjan, 2007) and cowpeas (Horax et al., 2004).

The protein band of $63 \mathrm{kDa}$ from SDS-PAGE (Fig. 1 \& 2) most likely corresponds to polypeptides with $\mathrm{pI}$ in the range of 6.4-7.5 and molecular weight of about $64 \mathrm{kDa}$ on the marama proteome map (Fig. 3).

To provide a better separation of basic protein of marama, proteomic analysis was performed on $13 \mathrm{~cm}$ strips, $\mathrm{pH}$ 6-11 (Fig. $3 \mathrm{~A}, \mathrm{~B}$ ). The proteome map of marama that was obtained with IPG strip pH 6-11 (Fig. 4 A-B) further confirmed differences in proteome patterns between marama and soya with respect to the high number of basic polypeptides in marama. Compared with other legumes, the protein profile of marama seemed to be different from those of peanuts (Kottapalli, Payton, Rakwal, Agrawal, Shibato, Murow \& Puppala, 2008) and protein-rich oilseeds like canola (Uruakpa \& 
Arntfield, 2006) and sunflower (Sammour, El-Shourbagy, Abo-Shady \& Abasary, 1995). Based on amino acid composition data of purified protein from this study and those published by Maruatona et al. (2010), marama protein contains less acidic amino acids content than soya. The proteome pattern of marama thus seems to be related to its amino composition.

Only one polypeptide in marama was tentatively identified by comparison with soya. This was spot 5 (Fig. $3 \& 4$ ), which appear to correspond with Glycinin G2: $A 2 B 1$, a subunit of the $11 \mathrm{~S}$ basic soya proteins. This single match with the $11 \mathrm{~S}$ soya proteins and the apparent absence of $7 \mathrm{~S}$ proteins indicates the storage proteins of marama are very different from those of soya.

Storage protein compositions have been found to significantly influence the functionality of protein properties (German, Damodaran \& Kinsella, 1982; Yuan, Yang, Tang, Zheng, Ahmad \& Yin, 2009). The absence of vicilin (7S) and the presence of more $11 \mathrm{~S}$ basic protein in marama may increase the stability of protein to heat and extreme $\mathrm{pH}$ 's as suggested for 11S basic soya glycinin (Yuan et al., 2009). The stability of basic $11 \mathrm{~S}$ of soya protein was associated with its high hydrophobicity compared with the acidic subunits and the total glycinin (11S) (German et al., 1982; Yuan et al., 2009). According to Creighton (1993), hydrophobic interactions are endothermic and therefore more stable at increasing temperature compared with hydrogen bonding and electrostatic interactions. A close look at the amino acid composition of marama revealed that its protein contains more aromatic amino acids. These together with the aliphatic amino acids may increase the hydrophobicity and stability of marama protein in comparison with soya. Further, the high tyrosine in 
marama may also contribute to the stability of its protein structure as described previously.

\section{Conclusions}

The protein composition of marama bean is very different from that of soya bean. The vicilin (7S) and the acidic $11 \mathrm{~S}$ subunits seem to be absent in marama protein. The only major proteins in marama are basic legumin (11S) and two additional proteins of relatively higher molecular weight. Also, marama protein seems to lack disulphide bonds. These findings suggest that marama protein may have increased heat stability compared with soya due to high hydrophobic interactions that are associated with the basic 11S. Since tyrosine is involved in polypeptide crosslinking, the tyrosine in marama may also contribute to the structural stability of its protein.

\section{ACKNOWLEDGEMENT}

This research work is a part of EU MARAMA II funded PROJECT (Contract no.: 032059).

\section{References}

Adebowale, A. Y., Adeyemi, A. I., Oshodi, A. A., \& Niranjan, K. (2007). Isolation, fractionation and characterisation of protein from mucuna bean. Food Chemistry, 104, 287-299.

Aluko, R. E., \& Yada, R. Y. (1195). Structure-function relationships of cowpea (Vigna unguiculata) globulin isolate: Influence of $\mathrm{pH}$ and $\mathrm{NaCl}$ on physicochemical and functional properties. Food Chemistry, 53, 259-265. 
Amonsou E., Taylor J., \& Minnaar, A. (2011). Microstructure of protein bodies in marama bean species. Lebensmittel-Wissenschaft und-Technologie, 44, 42-47.

AOAC (2000). Official Methods of Analysis (1 $7^{\text {th }}$ ed.). Rockville, Maryland: Association of Official Analytical Chemists.

Bidlingmeyer, B. A., Cohen A. S., \& Tarvin, L. T. (1984). The PICO-TAG method for amino acid determination. Journal of Chromatography, 33, 93-104.

Bradford, M. A. (1976). Rapid and sensitive method for the quantification of microgram quantities of protein utilizing the principle of protein-dye binding. Analytical Biochemistry, 72, 248-254.

Chel-Guerrero, L., Scilingo, A. A., Tintoré, G. S., Dávila G., \& Añón, C. M. (2007). Physicochemical and structural characterization of lima bean (Phaseolus lunatus) globulins. Lebensmittel-Wissenschaft und-Technologie, 40, 15371544.

Coetzer, L. A., \& Ross, J. H. (1976). Tylosema. Trees in S. Africa, 28, 77-80

Creighton, T. E. (1993). Proteins: Structures and Molecular Properties, $\left(2^{\text {nd }}\right.$ ed.) (pp. 290-300), Freeman, New York.

Duranti, M., Restani, P., Poniatowska, M., \& Cerletti, P. (1981). The seed globulins of lupinus albus. Phytochemistry, 20 (9) 2071-2075

German, B., Damodaran, S., \& Kinsella, E. J. (1982). Thermal dissociation and association behaviour of soy proteins. Journal of Agricultural and Food Chemistry, 30, 807-811.

Holse, M., Husted, S., \& Hansen, A. Chemical composition of marama bean (Tylosema esculentum) - a wild African bean with unexploited potential. Journal of Food Composition and Analysis (in press). 
Horax, R., Hettiarachchy, N. S., Chen, P., \& Jalaluddin, M. (2004). Preparation and characterization of protein Isolate from cowpea (Vigna unguiculata L. Walp.). Journal of Food Science, 69, 114-118.

Kinsella, J. E. (1979). Functional properties of soy protein. Journal of the American Oil Chemists Society, 56, 242-258.

Kottapalli, R. K., Payton, P., Rakwal, R., Agrawal, K. G., Shibato, J., Murow, M., \& Puppala, N. (2008). Proteomic analysis of mature seed of flour peanut cultivars using two-dimensional gel electrophoresis reveals distinct differential expression of storage, anti-nutritional, and allergenic proteins. Plant Science, $175,321-329$.

Levit, M. (1981). Effect of proline residue on protein folding, Journal of Molecular Biology, 145, 251-263.

Lqari, H., Vioque, J., Pedroche, J., \& Millan, F. (2002). Lupinus angustifolius protein isolates: chemical composition, functional properties and protein characterization. Food Chemistry, 76, 349-356.

Maruatona, G. N., Duodu, K. G., \& Minnaar, A. (2010). Physicochemical, nutritional and functional properties of marama bean flour. Food Chemistry, 121, 400405.

Mujoo, R., Trinh, T. D., Ng, K. W. P. (2003). Characterisation of storage proteins in different soybean varieties and their relationship to tofu yield and texture. Food Chemistry, 82, 265-273

Natarajan, S., Xu, C., Caperna, J. T, \& Garrett, M. W. (2005). Comparison of protein solubilisation methods suitable for proteomic analysis of soybean seed proteins. Analytical Biochemistry, 342, 214-220. 
Ripperger-Suhler, J. A. (1983). Protein quality of the African marama bean, Master thesis (pp. 26-28), University of Texas, Austin.

Sammour, R. H., El-Shourbagy, M. N., Abo-Shady, A. M., \& Abasary, A. M. (1995). Characterization of sunflower seed proteins by electrophoretic techniques. Arab Gulf Journal of Scientific Research, 13, 591-601.

Sheperd, A. D. (1979). Laboratory abrasive decorticating mill for small grains. Cereal Chemistry, 56, 545-548.

Takasaki, S., Kato, Y., Murata, M., Homma, S., \& Kawakishi, S. (2005). Effect of peroxidase and hydrogen peroxide on dityrosine formation and the mixing characteristics of wheat-flour dough. Bioscience Biotechnology and Biochemistry, 69, 1686-1692.

Taylor, J., Bean, S. R., Ioerger B. P., \& Taylor, J. R. N. (2007). Preferential binding of sorghum tannins with $\gamma$-kafirin and the influence of tannin binding on kafirin digestibility and biodegradation. Journal of Cereal Science, 46, 22-31.

Tilley, K. A., Benjamin, E. R., Bagorogoza, E. K., Okot-Kotber, M. B., Prakash O., \& Kwen, H. (2001). Tyrosine cross-links: Molecular basis of gluten structure and function. Journal of Agricultural and Food Chemistry, 49, 2627-2632.

Uruakpa, F. O., \& Arntfield, S. D. (2006). Impact of urea on the microstructure of commercial canola protein-carrageenan network: A research note. International Journal Biological Macromolecules, 38, 115-119.

Venkatachalam, M., \& Sathe, S. (2006). Chemical composition of selected edible nut seeds. Journal of Agricultural and Food Chemistry, 54, 4705-4714.

Yuan, D-B., Yang X-Q., Tang, C-H., Zheng, Z-X., Ahmad I. W-M., Yin, S-W. (2009). Physicochemical and functional properties of acidic and basic polypeptides of soy glycinin. Food Research International, 42, 700-706. 
Zarkadas, G. C., Gagnon, C., Poysa, V., Khanizadeh, S., Cober, R. E., Chang, V., \& Gleddie, S. (2007). Protein quality and identification of the storage protein subunits of tofu and null soybean genotypes, using amino acid analysis, onedimensional and two-dimensional gel electrophoresis, and tandem mass spectrometry. Food Research International, 40, 111-128. 
Table 1.

Protein yield and protein content (dry basis) of marama and soya protein extracts ${ }^{1}$

\begin{tabular}{lcc}
\hline Samples & $\begin{array}{c}\text { Protein content }(\mathrm{N} x \text { 5.71) } \\
(\mathrm{g} / 100 \mathrm{~g})\end{array}$ & $\begin{array}{c}\text { Protein yield } \\
\end{array}$ \\
\hline Marama extract & $86.1^{\mathrm{a}} \pm 1.5$ & $62.8^{\mathrm{a}} \pm 1.4$ \\
Soya extract & $85.6^{\mathrm{a}} \pm 1.3$ & $65.3^{\mathrm{b}} \pm 1.6$ \\
\hline
\end{tabular}

${ }^{\mathrm{T}}$ Mean $\pm \mathrm{SD}(\mathrm{n}=4)$ is reported;

Mean values with different superscript letters in columns are significantly different $(p<0.05)$ 


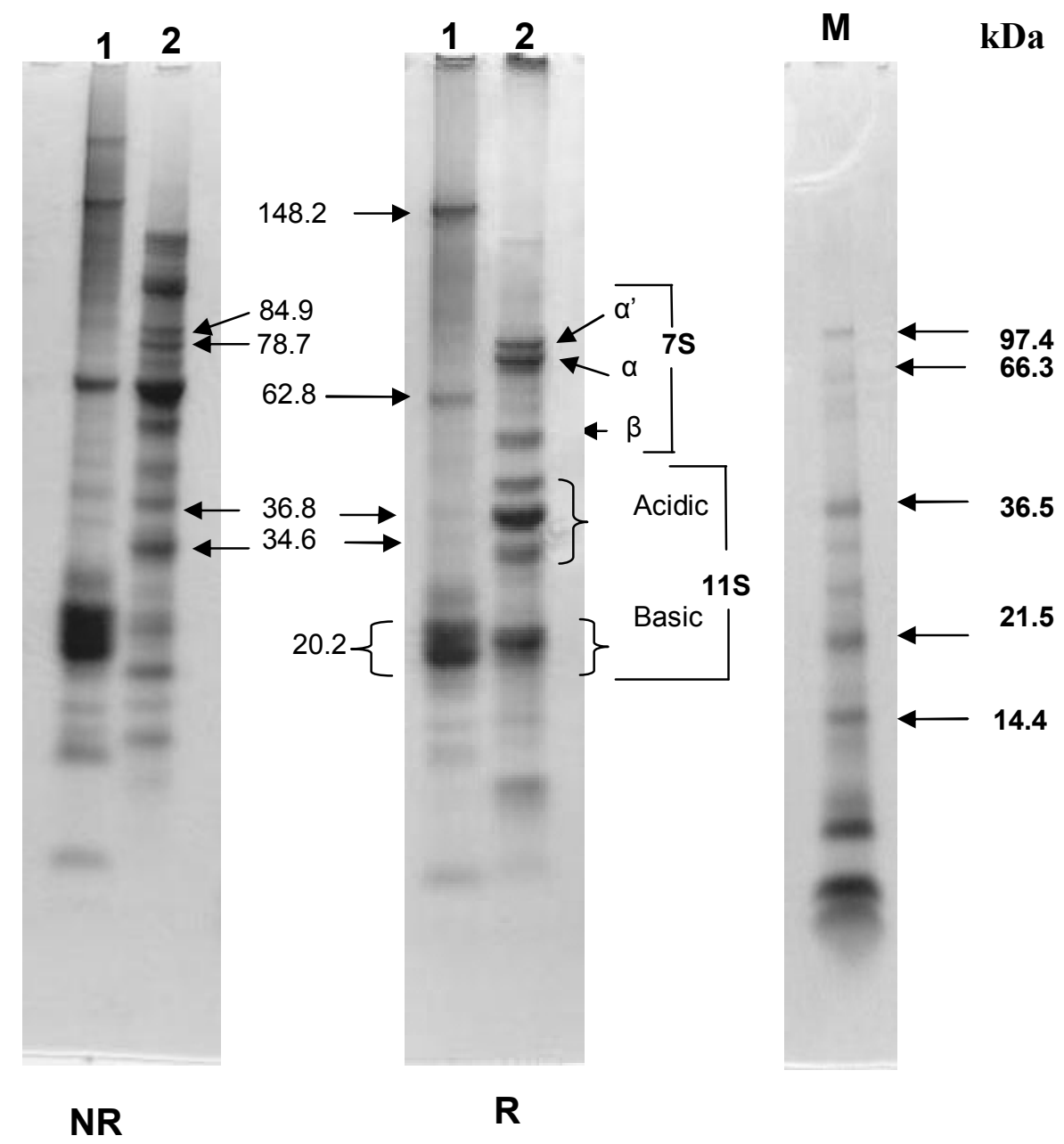

Fig. 1. SDS-PAGE profile of defatted marama and soya bean flours under nonreducing $(\mathrm{NR})$ and reducing $(\mathrm{R})$ conditions. Lane 1: Marama, Lane 2: Soya, Lane M: Molecular weight standards 


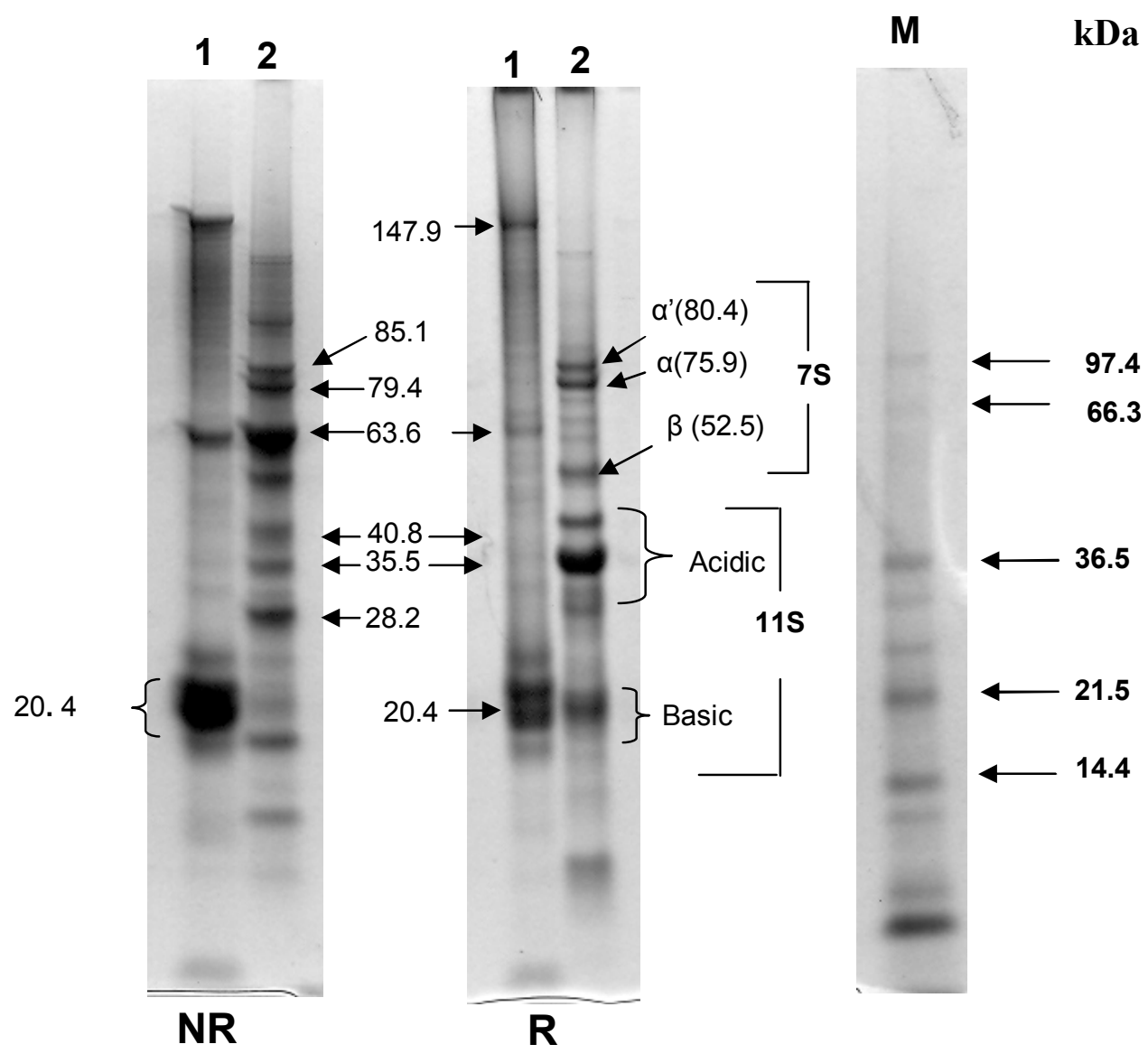

Fig. 2. SDS-PAGE profile of extracted marama and soya bean proteins under non-reducing $(\mathrm{NR})$ and reducing $(\mathrm{R})$ conditions. Lane 1: Marama, Lane 2: Soya, Lane M: Molecular weight standards 


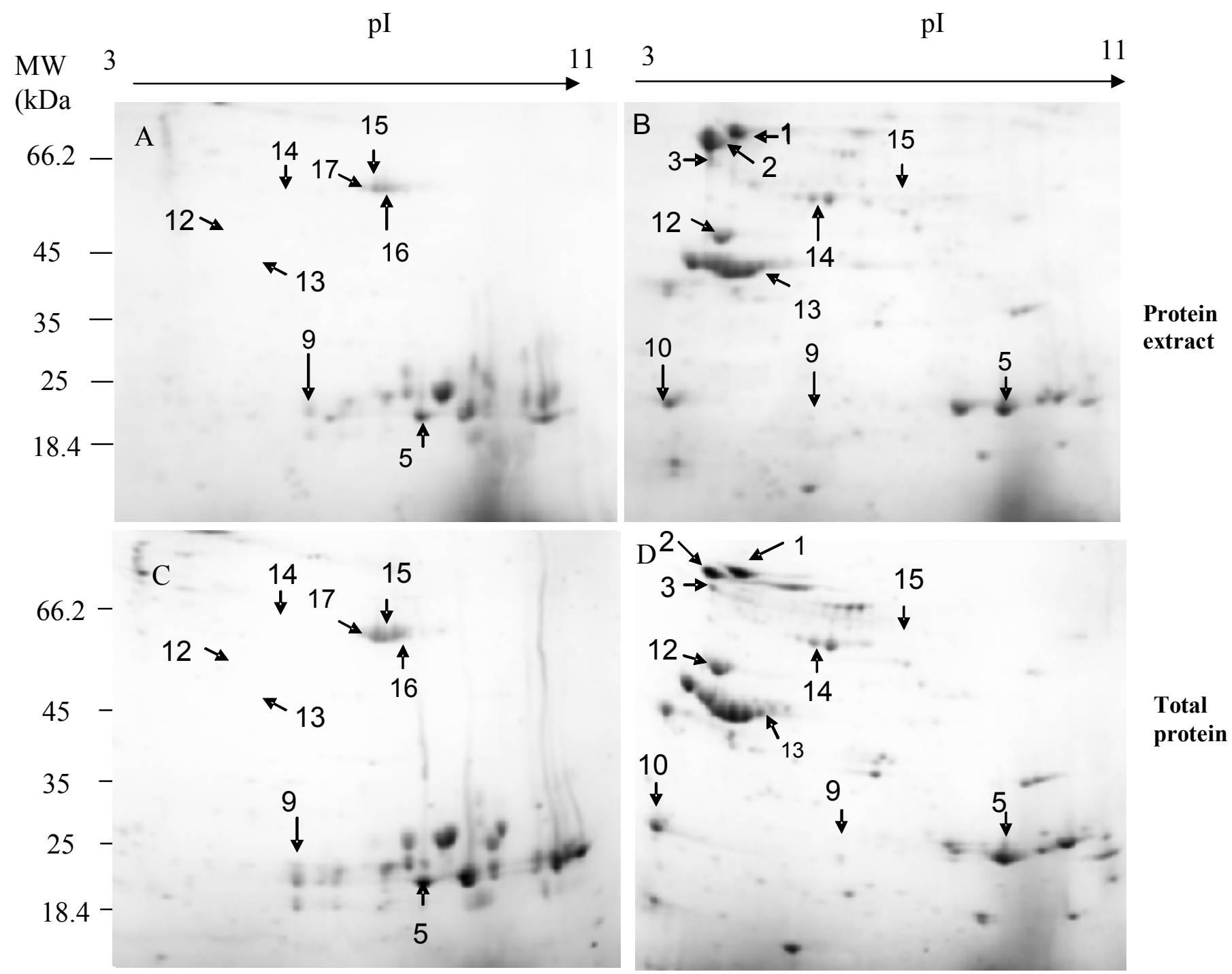

Fig. 3. Two-dimensional maps of marama (A \& C) and soya (B\& D)

proteins using Immobilized pH gradient (IPG) strips (3-11 Non Linear, NL).

A: marama protein extract, C: total marama protein, B: soya protein extract, D: total soya protein. 1:

$\alpha^{\prime}$-subunit of $\beta$ conlycinin, $2 \&$ 3: $\alpha$-subunit of $\beta$ conlycinin, 5: glycinin G2 A2B1, 10: soybean trypsin inhibitor, 12: Glycinin A3b4 subunit homohexamers, 13: Soybean proglycinin A1ab1b homotrimer, 14: $\beta$-Conglycinin $\beta$-homotrimer (Natarajan et al. (2005); Zarkadas et al. (2007); http://oilseedproteomic.missouri.ed). The same numbers on maps indicate spot matches. Spots 9, 15, 16,17 not identified. 

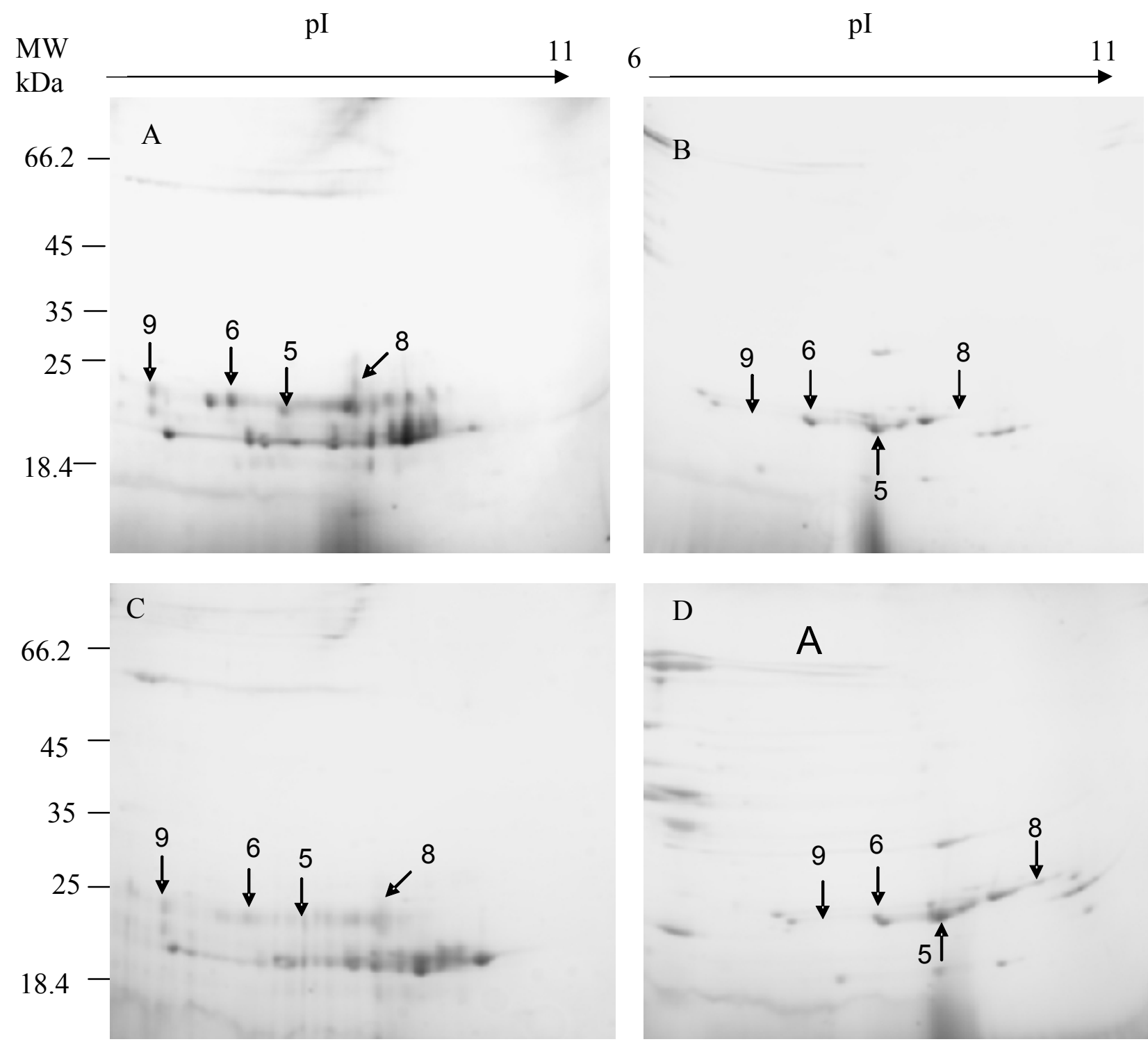

\section{Protein} extract

Fig. 4. Two-dimensional proteome maps of marama (A \& C) and soya (B\& D) proteins using Immobilized pH gradient (IPG) strips (6- 11).

A: marama protein extract, C: total marama protein, B: soya protein extract, D : total soya protein 5: Glycinin G2 : A2B1 (Natarajan et al., (2005); Zarkadas et al., (2007);

http://oilseedproteomic.missouri.ed). The same numbers on maps are used to indicate polypeptide matches. Spots $6,8,9$ not identified. 
Table 2.

Amino acid composition (g/100 g protein) of marama and soya flours and their respective protein extracts ${ }^{1}$

\begin{tabular}{|c|c|c|c|c|c|c|}
\hline \multirow[b]{2}{*}{ Amino acid (AA) } & \multicolumn{2}{|c|}{ Flours } & \multicolumn{2}{|c|}{ Protein extracts } & \multicolumn{2}{|c|}{$\begin{array}{c}\mathrm{FAO} / \mathrm{WHO}^{2} \\
\text { recommended pattern }\end{array}$} \\
\hline & Marama & Soya bean & Marama & Soya bean & $\begin{array}{l}\text { Pre-school } \\
\text { children } \\
\text { (2-5 years) }\end{array}$ & Adult \\
\hline Lysine & $5.7^{\mathrm{a}}$ & $6.3^{\mathrm{b}}$ & $6.6^{\mathrm{c}}$ & $6.9^{\mathrm{c}}$ & 5.8 & 1.6 \\
\hline Isoleucine & $4.3^{\mathrm{a}}$ & $4.7^{\mathrm{b}}$ & $5.0^{\mathrm{c}}$ & $4.9^{\mathrm{c}}$ & 2.8 & 1.3 \\
\hline Leucine & $7.9^{\mathrm{a}}$ & $9.8^{\mathrm{c}}$ & $7.8^{\mathrm{a}}$ & $9.4^{\mathrm{b}}$ & 6.6 & 1.9 \\
\hline Methionine & $1.0^{\mathrm{a}}$ & $1.5^{\mathrm{b}}$ & $1.2^{\mathrm{a}}$ & $1.8^{\mathrm{c}}$ & 2.5 & 1.7 \\
\hline Cysteine & $0.1^{\mathrm{a}}$ & $0.2^{\mathrm{b}}$ & $0.2^{\mathrm{b}}$ & $0.5^{\mathrm{c}}$ & & \\
\hline Phenylalanine & $3.7^{\mathrm{a}}$ & $4.0^{\mathrm{b}}$ & $4.1^{\mathrm{b}}$ & $4.9^{\mathrm{c}}$ & 6.3 & 1.9 \\
\hline Tyrosine & $11.4^{\mathrm{c}}$ & $3.9^{\mathrm{a}}$ & $9.1^{\mathrm{b}}$ & $4.0^{\mathrm{a}}$ & & \\
\hline Valine & $4.8^{\mathrm{a}}$ & $5.0^{\mathrm{b}}$ & $5.2^{\mathrm{b}}$ & $4.9^{\mathrm{a}}$ & 3.5 & 1.3 \\
\hline Threonine & $3.2^{\mathrm{a}}$ & $4.0^{\mathrm{b}}$ & $3.2^{\mathrm{a}}$ & $3.9^{\mathrm{b}}$ & 3.4 & 0.9 \\
\hline Histidine & $2.7^{\mathrm{a}}$ & $3.1^{\mathrm{b}}$ & $3.0^{\mathrm{b}}$ & $2.7^{\mathrm{a}}$ & 1.9 & 1.6 \\
\hline $\begin{array}{l}\text { Subtotal } \\
\text { Essential AA }\end{array}$ & 44.8 & 42.5 & 45.4 & 43.9 & & \\
\hline $\begin{array}{l}\text { Aspartic acid/ } \\
\text { Asparagine }\end{array}$ & $9.4^{\mathrm{a}}$ & $10.2^{\mathrm{b}}$ & $9.5^{\mathrm{a}}$ & $9.9^{b}$ & & \\
\hline $\begin{array}{l}\text { Glutamic acid/ } \\
\text { Glutamine }\end{array}$ & $15.2^{\mathrm{b}}$ & $18.9^{\mathrm{c}}$ & $13.2^{\mathrm{a}}$ & $19.0^{\mathrm{c}}$ & & \\
\hline Serine & $5.5^{\mathrm{a}}$ & $5.6^{\mathrm{a}}$ & 5.9 & 5.2 & & \\
\hline Glycine & $5.9^{\mathrm{b}}$ & $4.3^{\mathrm{a}}$ & $6.7^{\mathrm{c}}$ & $4.4^{\mathrm{a}}$ & & \\
\hline Arginine & $8.0^{\mathrm{c}}$ & $7.8^{\mathrm{b}}$ & $7.1^{\mathrm{a}}$ & $7.6^{\mathrm{b}}$ & & \\
\hline Alanine & $3.5^{\mathrm{a}}$ & $4.5^{\mathrm{b}}$ & $3.6^{\mathrm{a}}$ & $4.4^{\mathrm{b}}$ & & \\
\hline Proline & $7.2^{\mathrm{b}}$ & $5.5^{\mathrm{a}}$ & $8.3^{\mathrm{c}}$ & $5.2^{\mathrm{a}}$ & & \\
\hline $\begin{array}{l}\text { Subtotal Non- } \\
\text { essential AA }\end{array}$ & 54.7 & 56.8 & 54.3 & 55.7 & & \\
\hline Recovery & 99.5 & 99.3 & 99.7 & 99.6 & & \\
\hline
\end{tabular}

${ }^{\mathrm{I}}$ Mean $(\mathrm{n}=2)$ values with different superscript letters in rows are significantly different $(\mathrm{p}<0.05)$

${ }^{2}$ FAO/WHO (1989) recommended pattern (Pre-school children age 2-5 years; Adults) 
Table 3. Polypeptide distribution and matches between marama and soya protein $^{\mathrm{a}}$ $\mathrm{pH}$ range

\begin{tabular}{|c|c|c|c|c|}
\hline & \multicolumn{2}{|c|}{$\mathrm{pH} 3-11$} & \multicolumn{2}{|c|}{$\mathrm{pH}$ 6-11 } \\
\hline Samples & Marama & Soya & Marama & Soya \\
\hline Protein spots & $276 \pm 13$ & $286 \pm 21$ & $153 \pm 6$ & $96 \pm 5$ \\
\hline Tentative spot & \multicolumn{2}{|c|}{$52 \pm 5$} & \multicolumn{2}{|c|}{$26 \pm 7$} \\
\hline matches & & & & \\
\hline
\end{tabular}

